Religious Studies 40, 361-364 (c) 2004 Cambridge University Press

DOI: $10.1017 /$ S0034412504007103 Printed in the United Kingdom

\title{
Religions, truth, and the pursuit of truth: a reply to Zamulinski
}

\author{
T. J. MAWSON \\ St Peter's College, Oxford, OX1 2DL
}

\begin{abstract}
This paper provides a comment on Brian Zamulinksi's article in Religious Studies, 39 (2003), 43-6o. Contrary to Zamulinski's claim that religions are not truth-oriented but function as fictions, it is contended that they could not serve the purpose he assigns them unless their adherents regarded them as true. Religions must therefore be truth-oriented. The substantive question is whether any of them are true, and Zamulinski's paper provides no new method for addressing this question.
\end{abstract}

In a recent article in this journal, ${ }^{1}$ Brian Zamulinski offers us what he describes as 'a new argument to the effect that religions are not truth-oriented'. 2 Zamulinski tells us that if "religions were truth-oriented, they would be like historical or scientific works in terms of their function. The function of an historical or scientific work is to represent some aspect of the world accurately. If religions were truth-oriented, that would be one of their fundamental functions as well. ${ }^{3}$ As we read on, we find that, according to Zamulinski, rather than existing in order to do this, the function of religions is to satisfy a peculiarly human desire: religions are fairy-tales that we have created to 'relieve ... [the] psychological distress '4 that would accompany believing that there is 'morally random suffering'. ${ }^{5}$ "Religion "satisfies" a specific human longing for a state of affairs such that all is morally right with the world - in the same way that methadone "satisfies" the cravings of the heroin addict - and has come into existence to achieve that "satisfaction". '. 'The fundamental function of religion is to provide a particular sort of consolation. Its fundamental function is not to represent the world accurately. ${ }^{\prime 7}$ Zamulinski takes it that 'the question of whether religions are truthoriented is open, empirical and decidable', ${ }^{8}$ and thus offers several putative empirical facts about religions, facts which are - he suggests - more readily explained by his hypothesis than they are by the hypothesis that religions are truthoriented, systems of thought that do try to represent some aspect of the world accurately. It is important to stress that Zamulinski does not consider himself to 
be directly arguing that religions are not true; he considers himself to be directly addressing the prior question of whether or not they are even trying to be true, thus 'truth-oriented' rather than 'true'.

Of course, even if it is not a part of religions' fundamental function to represent the world accurately, one or more religions might nevertheless coincidentally end up representing the world more or less accurately. None of the shelves I put up in my room was intended to fall down under the weight of the books that I put on them; nevertheless, they (all) did fall down. As Zamulinski puts it: 'Saying that no religion exists because it is true does not entail that no religion is true. ${ }^{9}$ But, as Zamulinski points out, it 'would be astonishing if the characters and events depicted in a work of imagination that was not intended as a representation actually matched characters existing in and events occurring in the actual world' ${ }^{10}$ So, Zamulinski argues that if we accept his primary thesis that religions are not truthoriented, we should conclude that probably no religion is true. 'We could not be absolutely certain that no religion was true but it would be beyond a reasonable doubt that none was. '11 $\mathrm{He}$ does not consider himself to be directly arguing that religions are not true then, but he does think that he has an indirect argument from their lack of truth-orientation to their lack of truth. Thus Zamulinski concludes that

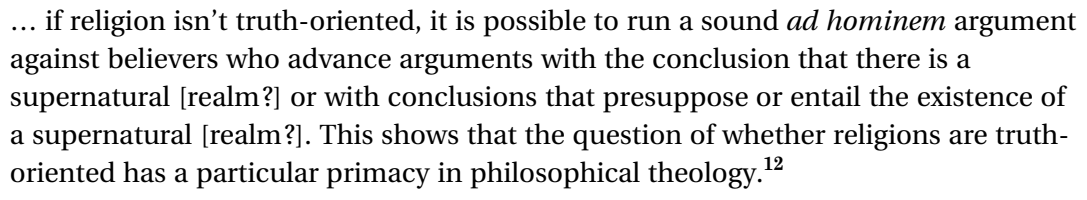

The thesis that religions are not truth-oriented is thus an interesting one that deserves investigation. I will argue simply that it does not have any 'primacy' in philosophical theology (or, more widely, in philosophical consideration of the supernatural).

Consider, by way of example, one of the main monotheistic religions: Islam. As with the vast majority of other religions, the Islamic religion tells a story about how it came into existence. It came into existence because God decided to reveal it to the Prophet Muhammad (through the Angel Gabriel). Does Islam give us any indication why God chose to reveal to Muhammad the things that he did? It does. It tells us that He chose to reveal these things to Muhammad because they were important spiritual truths that people had yet to discover. The Muslim is thus committed to believing that had the claims which make up the particular strand of monotheism that is Islam not been true - had Christianity, for example, been true - then God would not have made the claims that are the Islamic religion; $\mathrm{He}$ would have made other claims or none at all. Islam then asserts that it exists in part because it is true.

Similar stories abound in the first histories of most religions, monotheistic or not; and according to all religions, they exist because of the supernatural order 
that they reflect (everything exists ultimately because of the supernatural order, otherwise it wouldn't be the supernatural order), and they reflect it to some extent accurately because the supernatural order is such as to facilitate accurate reflection to that extent; it is not such as to defy any reflection whatsoever. Extreme apophaticism is the negation of thought about the supernatural, not an option within it. Thus Zamulinski's claim that 'Saying that no religion exists because it is true does not entail that no religion is true', ${ }^{13}$ is false. Saying that no religion exists because it is true entails that no religion is true, because every religion asserts (inter alia) that it itself exists because it is true. But is this just begging the question against Zamulinski, assuming that as religions are systems of thought about the supernatural, so they must see themselves as largely accurate representations of such and thus must see themselves as truth-oriented? Could not Zamulinski simply deny that all religions have this feature? He could not. Let us take the battle into his territory for a moment to see why.

If what Zamulinski would have us believe is the myth of a particular religion is to serve what Zamulinski would have us believe is its function - to provide consolation of the sort he sketches - then the adherents of that particular religion must take it to be true. To take another example: the monotheistic religions generally hold that after death there is a judgement, with some going thence to a heavenly reward and others to a hellish punishment. This belief - when combined with an optimistic assessment of one's own probable destination - can obviously serve to provide consolation of the sort Zamulinski suggests, but it can only do so if it is a belief that one holds, i.e. if one takes it to represent the world accurately. A consoling belief cannot remain a consoling belief if it ceases to be a belief and any mental state that one thinks does not represent the world accurately cannot be a belief; a fortiori it cannot be a consoling one.

One's beliefs just are those mental states that one takes to represent the world accurately, and thus were one to become convinced of Zamulinski's thesis that religions do not function to represent the world accurately, one would lose one's religious beliefs. And once lost, obviously they could no longer fulfil the function that Zamulinski suggests they must have, providing consolation. (It is no accident that placebo pills do not have the word 'placebo' imprinted upon them.) If Zamulinski is right about the function of religions, then every religious person must hold the view that his or her religious beliefs are true, and thus, a fortiori, that his or her religion is truth-oriented.

Zamulinski's hypothesis being true would thus entail that every religion is false and any religion's being true would entail that Zamulinski's hypothesis is false. So the question to which Zamulinski directly addresses himself - the truthorientation or otherwise of religions - cannot have any 'primacy' over the question of the truth of religions. We cannot think that a substantive investigation into whether or not religions are even trying to be true ('Are religions truth-oriented?') is one that could methodologically precede an investigation into whether or not 
any are successfully truth-oriented ('Are any actually true?'). We cannot expect to be able to reach the answer 'No' as a result of our first investigation (one conducted without assuming anything about the answer to the second question) and then run Zamulinski's 'sound ad hominem' argument to give us the answer 'probably No' to the second question.

Is there a God who has made us for Himself so that our hearts are restless until they find their rest in Him? Or do we make God for ourselves, as our hearts are restless until they find their rest in believing in Him? These are one and the same question: is there a God? It is an interesting question that deserves investigation. However, Zamulinski's argument offers us no new methodology for investigating it.

\section{Notes}

1. B. Zamulinski, 'Religion and the pursuit of truth', Religious Studies, 39 (2003), 43-6o.

2. Ibid., 43.

3. Ibid.

4. Ibid., 49.

5. Ibid.

6. Ibid.

7. Ibid.

8. Ibid., 46.

9. Ibid., 44.

10. Ibid.

11. Ibid.

12. Ibid., 60.

13. Ibid., 44. 